\title{
Psychiatry, Violence, and the Soviet Project of Transformation: A Micro-History of the Perm' Psycho-Neurological School-Sanatorium
}

\author{
MARIA CRISTINA GALMARINI-KABALA
}

This article analyzes the interactions of medical experts, minor patients, and parents in a child psychiatric institution that operated in the Soviet city of Perm' between 1926 and 1929. Through a micro-history of this institution, the author raises questions about the nature of violence within the realm of psychiatric care, demonstrating the multidimensional flow of power within a particular institutional setting and adding complexity to our understanding of the asylum writ large. At the same time, the article engages the question of violence in Soviet society at the end of the NEP, suggesting that the historical actors involved in the Perm' institution used violence as a means to explain the crisis of their time.

\section{Regionalisms and Imperialisms in the Making of the Russian Far East, 1903-1926}

\section{IVAN SABLIN AND DANIEL SUKHAN}

Tracing the emergence of the Russian Far East as a new region of the Russian Empire, revolutionary Russia, and the Soviet Union through regionalist and imperialist discourses and policies, this article briefly discusses Russian expansion in the Pacific littoral, outlines the history of regionalism in North Asia during the revolutionary and early Soviet periods, and focuses on the activities of the Far Eastern Council of People's Commissars (Dal'sovnarkom), the Far Eastern Republic (FER), and the Far Eastern Revolutionary Committee (Dal'revkom). Inspired by Siberian regionalism and other takes on post-imperial decentralization, the Bolshevik Aleksandr Mikhailovich Krasnoshchekov and other regional politicians became the makers of the new region from within. Meanwhile, the legacies of the empire's expansionism, the Bolshevik "new imperialism" in Asia, and the Japanese military presence in the region during the Russian Civil War accompanied the consolidation of the Russian Far East.

\section{Riding the Soviet Iron Horse: A Reading of Viktor Turin's Turksib through the Lens of John Ford}

\section{INGRID KLEESPIES}

This article considers Viktor Turin's 1929 film Turksib to be a “Red Western," or film that is indebted to an American cinematic, visual, and literary tradition in its production of a vision of a Soviet frontier. Turksib engages with a discourse of frontierority that proved central to the articulation of Soviet identity in the 1920s and early 1930s. Drawing from prerevolutionary cultural paradigms for Russian national and imperial growth, as well as from the key American myth of the train's role in vanquishing the frontier, Turksib is a film meant to realize notions of territorial largesse in an ideologically-acceptable manner-that is, to reconfigure the dominant imperialist-capitalist 
model of the frontier in socialist terms. A close study of Turin's film in comparison to its western counterpart, John Ford's early classic, The Iron Horse (1924), reveals the challenge of distinguishing industrialization and modernization in socialist and avowedly anti-imperial rather than capitalist and colonial terms.

\title{
The Shop Window Quality of Things: 1920s Weimar Surface Culture in Nabokov's Korol', dama, valet
}

\author{
LUKE PARKER
}

By resituating the original 1928 Russian version of Korol', dama, valet (King, Queen, Knave) in the context of Weimar Berlin, this article shows that Vladimir Nabokov's second novel is the culmination of a serious engagement with a flourishing German visual and commercial culture. The appeal of Korol', dama, valet to both native Germans and Russian émigrés based in Berlin is shown to be a sympathetic yet strategic manipulation of the tropes and commonplaces of Berlin's renowned "surface culture.” The article presents Nabokov as an entrepreneurial figure, exploiting his ambivalent status as both an insider and outsider in Berlin for success in translation as well as among the Russian émigrés. Uncovering Nabokov's complex relations to European visual culture, I show that the fusion of materiality and display in Korol', dama, valet can be understood through the concept of the "shop window quality of things." Drawing on contemporary German sources, this article reveals the Russian novel, so thoroughly repurposed thirty years later in the 1968 English translation, to be a perceptive, even prophetic, analysis of a dynamic and attractive Weimar culture already beginning to spin out of control.

\section{In Defense of Native Literature: Writers' Associations, State and the Cult of the Writer in pre-1945 Bulgaria}

\author{
IRINA GIGOVA
}

Looking at Bulgarian society and cultural life of the first half of the 1900s, this study scrutinizes a common belief in the high public esteem reserved for poets and writers in eastern Europe. It demonstrates that the creators of literature (and the national arts in general) occupied a precarious position in a society without a sustainable cultural market. The predicament of Bulgarian writers, however, was that of many European literati in early 1900s competing for readers' attention with a rising mass culture. Placing Bulgarian writers in a broader interwar framework, this article explores the various non-literary strategies they pursued in affirming the public value of national literature. In the process, it suggests that the lore of "the writer as a national hero" was the deliberate work of social actors seeking to correct an unsatisfying reality and not an expression of an organic relationship between nation and writers (and intellectuals more broadly).

\section{Seeing the Bigger Picture: Conspiratorial Revisions of World War II History in Recent Russian Cinema}

\section{BORIS NOORDENBOS}

This article analyzes revisions of World War II history in recent Russian cinema and television, including the feature film The Match (Andrei Maliukov, 2012), 
Spy (Aleksei Andrianov, 2012), and the television series Liquidation (Sergei Ursuliak, 2007). All these productions rely on the logic of conspiracy theory for their reimaginations of war history: pivotal developments during the war or its aftermath are presented as the result of subterranean manipulations by enemies or intelligence services. Through a narrative and visual analysis, the article shows how these films and series use the notion of conspiracy to reformat the contexts of wartime events and to place them within a speculative "bigger picture." In doing so, they infer that what we know about the past is merely a part or effect of larger, hidden designs. Finally, the article situates these findings within a wider "reconciliation with the Soviet" in Putin-era culture, which increasingly centers on the remembrance of World War II. 